\title{
RESTRICTED
}

LC/CAR/R. 203

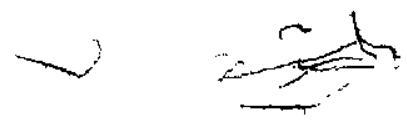

Date: 14 March 1986

ORIGINAL: ENGLISH

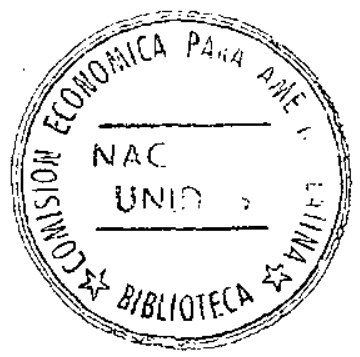

TOWARDS BIBLIOGRAPHIC CONTROL IN THE CARIBBEAN:

THE CARIBBEAN INFORMATION SYSTEM

Prepared by

Judith Modeste and Cathy Shepherd

This document has been prepared without formal editing. The authors are staff members of the United Nations Economic Commission for Latin America and the Caribbean Subregional Headquarters for the Caribbean. This document was prepared as an article for the International Federation of Library Associations and Institutions Journal. The views expressed are the exclusive responsibility of the authors and do not necessarily coincide with those of ECLAC. 


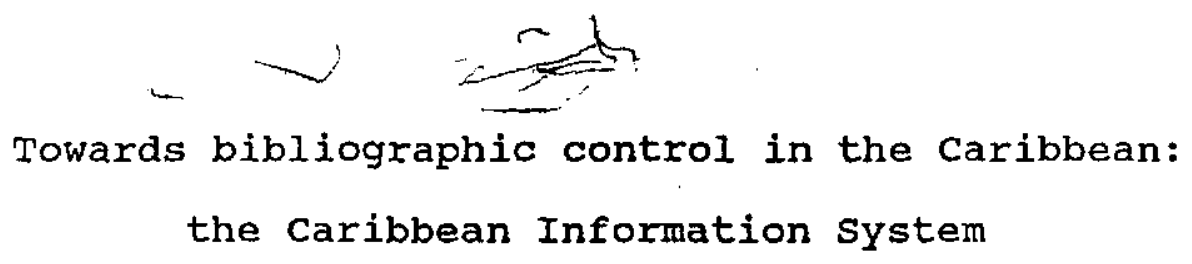

by

Judith Modeste and Cathy Shepherd

The authors are staff members of the United Nations Economic Conmission for Iatin Arerica and the Caribbean. The views expressed in the paper do not necessarily reflect those of the Organization. 
INTRODUCTION

The Caribbean Information system is a decentralized information system encompassing sectoral library networks in the Caribbean and providing access to information about the region and externally produced technical information relevant to the region's development. The system was mandated by the caribbean Development and Co-operation committee (CDCC), a permanent subsidiary body of the Economic Commission for Latin America and the Caribbean (ECLAC). All twenty countries served by the CDCC have agreed to membership of the system.

The first sectoral network to be established was the Caribbean Information system for Economic and social Planning (CARISPLAN). It was designed to support social and economic planning and research and development at national and subregional levels, by making timely and relevant information available to each country according to existing and potential user needs. other sectoral networks indvarying stages of development are: the Caribbean Agricultural Information system (CAGRIS), the Caribbean Patent Information Network (CARPIN), the Caribbean Science and Technology Network (CARSTIN) and the Caribbean Energy Information System. 
THE CARIBBEAN INFORMATION SYSTEM FOR ECONOMIC AND SOCIAL PLANNING (CARISPLAN)

structure

CARISPLAN attempts to achieve maximum coverage of development literature produced in or about the caribbean, with emphasis on non-conventional literature not covered by normal bibliographic control. It restricts itself to documents written in English, Spanish, French and Dutch - the four official languages of the CDCC member states.

Each participating centre, through its information unit, identifies and collects the national literature relevant to the scope of the network, prepares bibliographic records and organizes the documents for easy retrieval. Co-ordination at the national level is done by the national focal point, generally the national planning agency, and at the regional level by the Caribbean Documentation Centre.

\section{Services and products}

The system currently provides access to current and retrospective economic and social planning and development literature and to technological information contained in patents granted in the caribbean, and to a limited extent, access to world development. literature available through regional and international systems. The principal product of the system is at present a data base from which CARISPLAN Abstracts, a quarterly journal is produced. This data base has been built up from 
bibIiographic records which reflect the holdings of the caribbean Documentation Centre, national focal points and participating centres. The monthly current Awareness Bulletin disseminates references to current literature on the region and on areas relevant to the governments. Specialized bibliographies on priority areas are prepared on demand.

The CARPAT data base is also maintained at the centre and provides information on available patents. The patent Information and Documentation Unit (PIDU) plans to provide current awareness listings and to maintain search files of relevant technological information contained in patent documents and non-patent literature, in support of technical and industrial (economic) development.

The Centre provides the following reference services free of charge to participating centres and individual users: question and answer services, information searches, referral services, inter-library loans, SDI and document delivery.

In the interest of developing the regional information infrastructure, the system provides:

- technical assistance, advisory and consultant services

- training of librarians in specialized methodologies

- user education.

These services are accomplished through missions, meetings with policy-makers and planners, national and regional workshops. 


\section{Universal availability of publications}

The Centre has made a contribution in the area of availability of publications through an aggressive acquisitions policy and free document delivery to CDCC member countries and other interested agencies. In the light of postage costs, document delivery is to be developed based on the preparation and distribution of microfiche to national focal points and participating centres.

\section{Standardization}

standardization and cofpatibility with regional and international systems were paid much attention to in the design Of CARISPLAN.

At the international level, the Caribbean Information system is a component of DEVSIS and in Latin America, CARISPLAN is linked with INFOPLAN - the Latin American Information System for Planning. The bibliographic record card used, is based on the UNISIST Reference Manual for machine-readable bibliographic description, 2 ed. The $\underline{A C C R} 2$ and the OECD Macrothesaurus are used in cataloguing, and indexing activities to ensure compatibility with regional and international systems and to maintain consistency within the data base.

MINISIS, the software package used by CARISPLAN and CARPIN, supports the exchange of data by accepting and producing magnetic tapes that conform to ISO standard 2709 including MARC, UNISIST 
and CCF formats. Compatible with the ISIS and CDS/ISIS micro packages, it is available free of charge to developing countries, factors which ensure its compatibility with the development of information systems worldwide.

The Documentation Centre has acquired new resources which will have the capability to respond to increasing demands from CDCC member states and institutions for advice and guidance on the use of appropriate information technology.

\section{CONCLUSION}

CARISPLAN has significantly improved access to nonconventional development literature produced in the region but this access is not yet complete. Several countries do not have a policy of declassification of locally produced documents or of deposit of these in the national focal point. 160 libraries now participate in the system, of these, 18 libraries serve as focal points.

All participating centres use the standardized procedures for abstracting, indexing and preparation of bibliographic records and several centres use an abbreviated form of the bibliógraphic record card for recording their holdings.

In the larger member states national socio-economic information networks are organized. In one case, an abstracting journal is published regularly. Several focal points produce current awareness bulletins. A project to enable one focal point 
to have on-Iine access to CARISPLAN and other sectoral data bases, input data and create its own data bases has been established. 